\title{
Fiesta del Modernismo: patrimonio y tradición en un marco festivo de la Colònia Güell
}

La Fiesta del Modernismo de la Colònia Güell es una recreación teatral en la calle de escenas de la vida cotidiana de esta colonia industrial textil de hace cien años. Esta recreación, protagonizada por los propios vecinos, se celebra en un contexto festivo y en el marco de la arquitectura modernista de la colonia. La fiesta se celebra una vez al año, habitualmente el fin de semana después del Pilar (12 de octubre).

Marta Barceló | Ayuntamiento de Santa Coloma de Cervelló

URL de la contribución <www.iaph.es/revistaph/index.php/revistaph/article/view/4099>

Santa Coloma de Cervelló es un pequeño municipio del Baix Llobregat, en una comarca densamente poblada situada a 13 kilómetros de la ciudad de Barcelona. En el municipio se encuentra la Colònia Güell, con un valioso patrimonio arquitectónico y social, orgullo de todos sus habitantes. La Colònia Güell ha sido declarada conjunto histórico-artístico (1969), bien de interés cultural (1991) y la Cripta Gaudí, obra crucial del modernismo catalán, fue declarada patrimonio de la humanidad por la UNESCO (2005).

La historia de la Colònia Güell es un claro ejemplo del impulso que tuvo la industria textil en la revolución industrial en Cataluña. En 1890 se fundó la fábrica y cuatro años más tarde empezaron a construir las primeras viviendas para los obreros y sus familias con

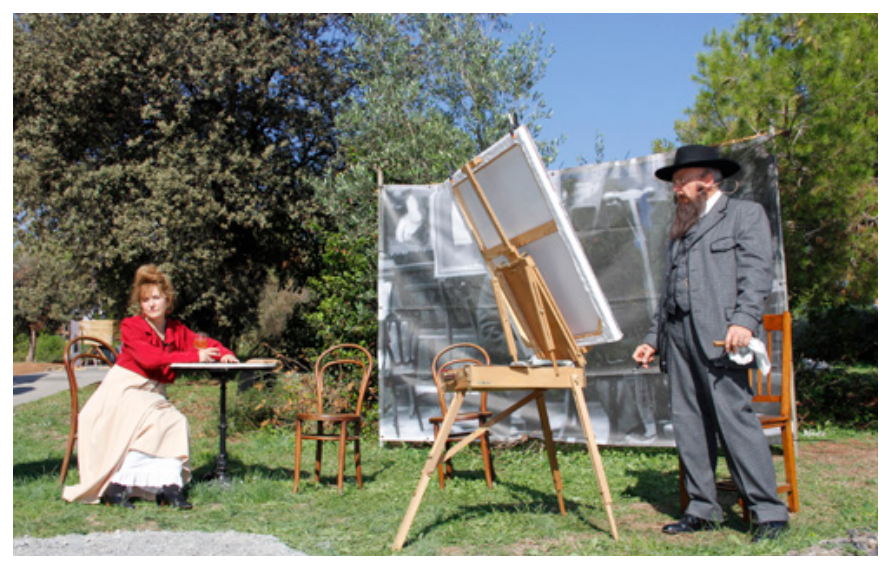

Cuadro de Ramón Casas | foto José Antonio Albert, autor de todas las imágenes sus correspondientes equipamientos. Don Eusebi Güell y Bacigalupi, con el título de conde Güell, importante industrial, protector de la cultura y un mecenas de artistas, arquitectos, músicos, poetas y novelistas, fue el impulsor de este proyecto.

Esta atmósfera del siglo XIX que todavía está presente en las calles de la Colònia Güell es lo que la hacen tan especial. La Colònia Güell conserva todavía un importante patrimonio histórico y artístico, que en el transcurso de los años, se ha adaptado a la época y a un nuevo modelo social que nada tiene que ver con la vieja estructura de Colònia industrial. Sin embargo, ha conservado un paisaje arquitectónico que nos evoca vivamente un tiempo pasado.

Las Fiestas del Modernismo reflejan la atmósfera más genuina de la Colònia Güell. Se vienen celebrando desde hace 17 años durante un fin de semana del mes de octubre y están organizadas por la Asociación La Colònia Modernista y el Ayuntamiento de Santa Coloma de Cervelló. La asociación se fundó en el año 2001 con el objetivo de promover el legado histórico, cultural, artístico, arquitectónico, antropológico e industrial de la Colònia Güell.

La fiesta recrea determinados elementos de la vida de la Colònia de cien años atrás. Esta recreación utiliza el método "historia viva", mediante teatralizaciones en sus calles y otras actividades culturales, encuadradas todas ellas en un contexto festivo y en el marco arquitectónico incomparable de la propia Colònia. Durante la fiesta, 


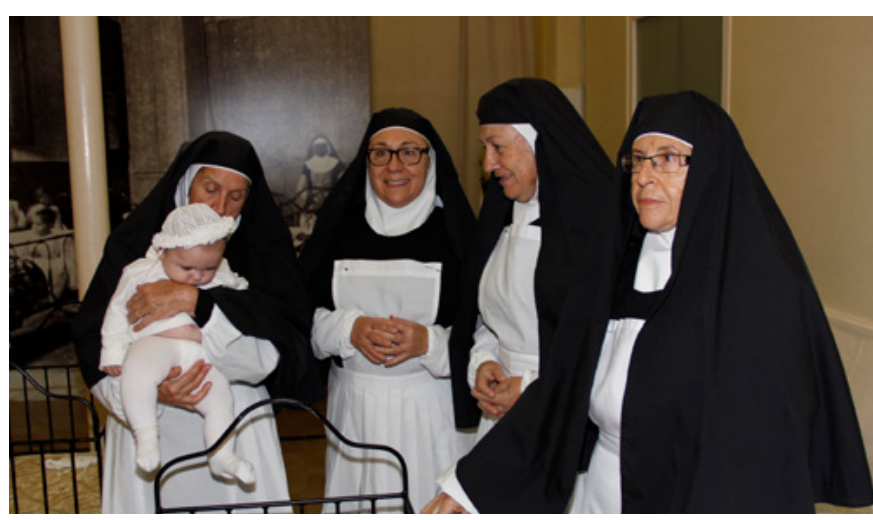

Cuadro de la escuela cuna en el edificio del Casal de las Monjas

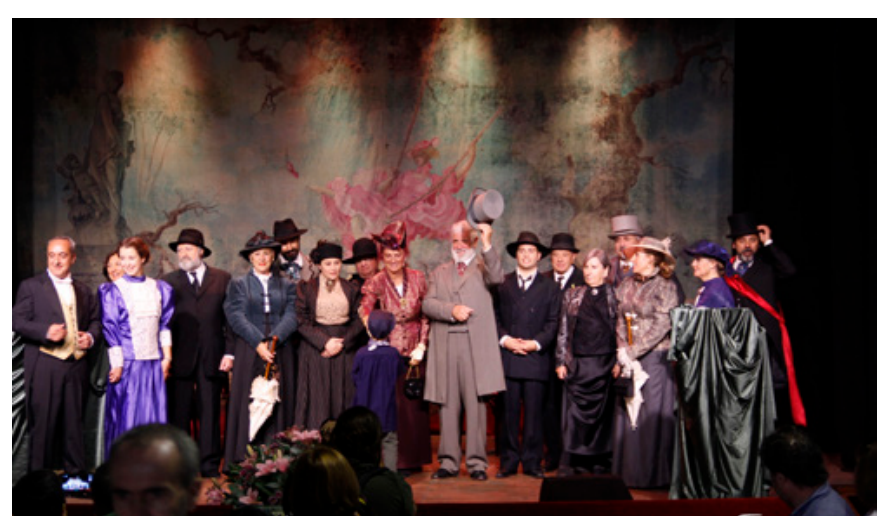

Las autoridades en la inauguración del teatro

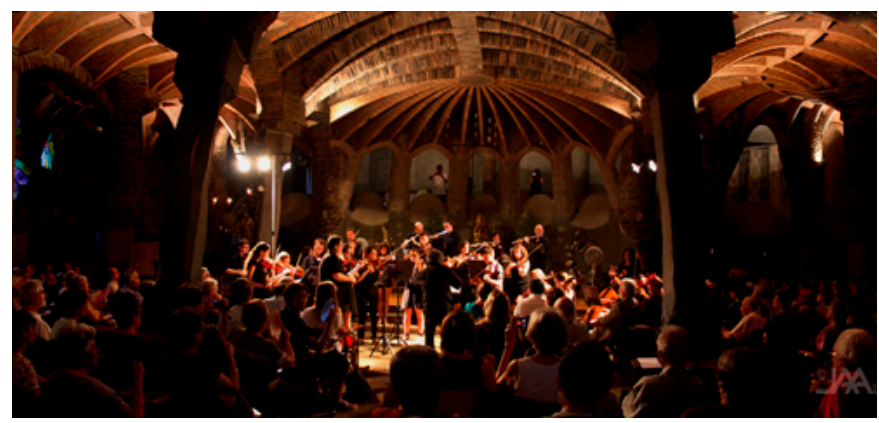

Cripta Gaudí

también hay exposiciones de carácter histórico o cultural en general. De esta manera se pretende mostrar aspectos de la vida social de esta Colònia crepuscular, tanto los elementos de arqueología industrial que contiene como su arquitectura, lo más fielmente posible a la historia. Más aún, divulgando el conocimiento se pretende contribuir a la preservación de su identidad, la conservación de su patrimonio y la cohesión de su vecindario. La misma idiosincrasia de la fiesta ha provocado la recopilación y producción de utensilios, elementos de atrezo, y se han confeccionado más de 200 vestidos que aportan un valor añadido al patrimonio tangible de la Colònia Güell.

La última Fiesta del Modernismo tuvo lugar los días 20, 21 y 22 de octubre de 2017. Como cada año, la trama argumental corresponde a vivencias que han sucedido en la Colònia en el entorno del Modernismo, a finales del siglo XIX y principios del siglo XX, destacando siempre algún hecho significativo. En esta edición se conmemoraba el $125^{\circ}$ aniversario de la inauguración del teatro Fontova y la cesión de los terrenos por parte de Eusebi Güell para construir la iglesia proyectada por el arquitecto Antoni Gaudí i Cornet, arquitecto modernista catalán reconocido internacionalmente como uno de los genios más relevantes de la disciplina. Se recrearon más de 20 espacios teatralizados con argumentos de la época, en el entorno de los edificios de arquitectura modernista.

La celebración de esta fiesta además de ser un medio de recuperación de memoria histórica también es un elemento de cohesión social, puesto que para su realización es imprescindible la colaboración voluntaria de vecinos, entidades y comercio. Las personas implicadas, ya sea las de la organización, los actores y los técnicos, son es su gran mayoría vecinos del mismo municipio de Santa Coloma de Cervelló.

Después de todos estos años podemos decir que las Fiestas del Modernismo han sido un vehículo ideal para conocer mejor el origen de la historia de la Colònia, tanto para los visitantes como para los propios habitantes. El objetivo de la Asociación La Colònia Modernista es continuar con este proyecto que aporta un valor añadido al legado histórico ya destacado de la Colònia Güell.

\section{+ Información}

Ajuntament de Santa Coloma de Cervelló

www.santacolomadecervello.cat

Asociaciò La Colònia Modernista

info@coloniamodernista.cat

www.coloniamodernista.cat 